\title{
Baptists and Bootleggers? The Basel Convention and Metals Recycling Trade
}

\author{
Aynsley Kellow
}

D RAWING upon the analogy of restrictions on the sale of alcohol, Bruce Yandle (1989) has suggested that most environmental policies that succeed in getting adopted are supported by coalitions of 'baptists' and 'bootleggers'. In this analogy, the baptists want the sale of liquor on the Sabbath banned because it is sinful; the bootleggers want it banned because only that way can they make any money.

This view touches on some problems in regulation, although it does not quite capture all the elements of regulatory failure. As well as creating opportunities for criminals to profit, regulation can create incentives for behaviour which, while lawful, is unintended and sometimes perverse and the opposite of the policy-maker's intention. But Yandle's insight is especially appropriate for the Basel Convention, especially as amended so as to ban trade in hazardous wastes. The Basel Convention, concluded in 1989, established a prior informed consent (PIC) regime governing international trade in hazardous wastes. This regime was extended by an amendment negotiated in 1995 which banned trade in wastes between OECD and non-OECD nations even when that waste was destined for recycling or recovery.

\section{Interests and Morality in Environmental Issues}

Most environmental issues involve a mixture of interests and morality. The word 'pollution' referred to moral contamination long before it came to be applied to environmental phenomena (see Douglas, 1992), and environmental pollution cannot be reduced to a scientific statement about the presence of a specified amount of a substance in a certain location in the environment. 'Pollution' involves both science and some evaluative dimension: a presumption that the presence of the substance is either wrong or at least valued negatively. In the politics of toxic waste, the moral view of waste predominates over the economic view, which holds that the production of waste (up to a point) can be socially beneficial.

The basis for the necessary evaluative aspect of pollution can therefore be either economic cost or morality. Commonly, the two are bound up as two facets of the same evaluation, and are mutually consistent. The moral judgments combine with the economic costs to produce support for policy action. But in the term 
'waste', they combine in such a way as to make effective policy responses problematic.

'Waste' is something with negative economic value. This sets up a particular kind of policy problem, since the waste industry involves an inverse exchange relationship between materials and cash: operators handling waste receive both payment and their raw materials simultaneously, and thus face a strong incentive to dispose of their waste as cheaply as possible, which often means illegally (Wynne, 1987:76-7). Waste operators are thus frequently in breach of the law, and regulations that increase the cost of disposal often simply serve to increase the incentives for bootlegging.

The waste industry is thus easy to demonise. It deals with something which has negative economic value and creates risks for humans and the natural environment. It attracts unscrupulous operators and provides profits attractive enough to invite participation by organised crime. Greenpeace could plausibly characterise those engaging in trade in hazardous waste as 'toxic criminals', arguing that waste generation should be minimised by strong regulation, and the export of wastes to developing nations banned as 'toxic colonialism'. Greenpeace (1994) praised the ban decision taken at the Second Conference of the Parties to the Basel Convention (COP-II) in 1994 in the following terms: 'For the first time in international law the Basel parties took a clear political decision that hazardous waste is not a "good" suitable for uncontrolled free trade, but rather is something to be avoided, prevented or cured, like a disease or a dangerous plague.'

Yet the generation of some waste is inescapable, and the 'baptist' approach of Greenpeace increases the incentives for illicit disposal, creating opportunities for bootleggers. We might disapprove of waste, but we still have to manage it, and this requires us to organise enterprises to handle it and institutions to govern this process. Moralising does not assist much with either of these tasks.

The appropriateness of the bootleggers-and-baptists analogy extends to the effects of this regulatory failure, which include not just profits for bootleggers but numerous unanticipated consequences and even counterproductive results. As Louka (1994) has pointed out, moral convictions are not useful prescriptions for the development of successful international policies. Among other things, she argues, considering wastes as morally reprehensible undermines their management and minimisation because it induces reputable waste management enterprises that could invest in methods of treatment and reduction to withdraw from the industry.

International prohibition regimes usually prove to be particularly ineffective in suppressing activities that require limited commitments of readily available resources, require no particular expertise to commit, can be readily concealed, are unlikely to be reported to authorities, and for which consumer demand is substantial, resilient, and not readily met by substitute activities or products (Nadelmann, 1990). International society lacks either the coercive capacity or the cultural homogeneity to produce social sanctions sufficiently strong ever to produce a global regime to ban trade in things like drugs as effectively as regimes to combat piracy, 
slavery or even counterfeiting and hijacking, and the worst components of the hazardous waste trade are arguably in the same category as drugs.

Nadelmann (1990:523) points out that the danger of moving to increasingly prohibitory and punitive approaches in global environmental regimes is that the violators will evolve from legitimate corporations able to contend with civil fines and 'white collar' charges into 'entirely criminal organisations and individuals willing to assume greater risks in return for greater profits'.

Groups like Greenpeace and the Basel Action Network clearly constitute the baptists on the Basel issue. Their goals of ensuring that people and the environment are not harmed by hazardous waste are laudable; but their remedy runs the risk of exacerbating the problem. The Basel prohibition regime has considerable potential to cause problems with waste destined for final disposal, and environmental crime is an important growth area. Here, however, we will focus on what was at stake with the ban on trade in recyclables from the perspective of metals.

We shall examine the trade in metal wastes for recovery and recycling and the consequences of the Basel ban, and then consider who the bootleggers might be who have helped drive the policy processes that have produced such a poor piece of international policy.

\section{Metals and the Basel Ban}

Recycling rates for non-ferrous metals are significant. The rate for copper is estimated at around 40 per cent, zinc 30 per cent, lead 50 per cent, and aluminium 25 per cent. ${ }^{\prime}$ For steel it is 50 per cent. Recycling non-ferrous metals can save energy and reduce pollution, water use, and the production of mining wastes. The industry employs 500,000 people in OECD countries and has a worldwide annual value of about $\$ 20$ billion. Trade in metal scrap and residues between OECD countries is estimated at $\$ 32.6$ billion. Exports from OECD to non-OECD countries total $\$ 8.2$ billion, with OECD imports from non-OECD countries $\$ 4.3$ billion and trade among non-OECD countries $\$ 1.8$ billion (Hoffman, 1995). Some of this trade consists of ashes or residues recovered from one refining operation from which commercial metal could be recovered, but only at a small number of custom refineries.

A review of toxic waste in the UK published by World Wildlife Fund in 1992 barely mentioned non-ferrous metals (Allen, 1992), which suggests that trade in non-ferrous metals may pose no problem. Even Greenpeace does not appear to have much evidence that there was a problem with trade in recyclable metals; few of its press releases in the period of COP-II and the Third Conference of the Parties (COP-III) in 1995 contained any. Among about 20 cases of dumping, metals recycling was at issue in only three, and it was possible that the problems arose from lack of domestic regulation.

Environmental groups regard the recycling of discarded electronic equipment, including printed circuitry, as a significant problem. But Greenpeace's example of

${ }^{1}$ Rates are somewhat higher in the US: 38 per cent for aluminium, 71 per cent for lead in 1992. 
the export of Australian computer scrap to the Philippines does not sustain its claims that it is a case of 'toxic colonialism' and, on the eve of Basel COP-II, that Australia is 'the world's number one toxic criminal'. Trade in computer scrap to the Philippines was being conducted by Hightechnology Metal Recycders Pty Ltd, which purchased obsolete electrical and electronic equipment and extracted from it base metals and components (Thompson Environmental Services, 1995:6). This was then shipped to the Philippines, where a subsidiary company, Computer Recyclers (Aust) Phils., Inc, used manual labour to recover computer parts such as diodes, switches, heat sinks and capacitors, which were exported for reuse in Australia, the US, Vietnam and China. Clean copper, aluminium, brass and stainless steel were sorted and exported to buyers in the same countries, while ferrous steel scrap was sold to local buyers. Plastic scrap was exported to Malaysia and China; printed circuit boards and other items requiring pyrometallurgical or hydrometallurgical recovery were sent to Australia, where gold, silver and copper were recovered. So the most hazardous part of this recycling operation was conducted in Australia.

This case demonstrates the comparative advantage in the supply of labour for the recycling operation which the Philippines enjoys and the gains from trade which can be enjoyed, from an economic as well as an environmental perspective. If the recycling operation could not take advantage of cheap labour costs for disassembly, less metal would be recovered from used computers, resulting in more being disposed of in dumps, as well as in fewer jobs for Philippines workers and other fruits of economic activity.

Computer scrap has been recycled at a plant in Canada for 20 years. More than 100,000 tonnes were recycled in 1993 , yielding metal valued at over $C \$ 200 \mathrm{~m}$. The metal recovered included 34,000 tonnes of copper, 123 tonnes of silver, 7.1 tonnes of gold and 5 tonnes of platinum and palladium. These amounted to (respectively) 5 per cent, 14 per cent, 5 per cent and 37 per cent of the amount of these metals produced in Canada by mining (Veldhuizen \& Sippel, 1991).

Recycling typically uses less energy and produces substantially less waste than production from mining concentrates, and has the added advantage of removing the recycled products from landfill. One would expect environmental policy to encourage the development of such industrial processes, which mark a positive step towards the development of a sustainable economy; yet the opposite is the case. Rather, the international waste regime limits the development of such industries, particularly in developing countries.

In November 1992 Canada adopted regulations giving effect to the Basel Convention. While imports from non-OECD countries were still allowed, there were some perverse effects. For example, circuit boards could not be imported into Canada in shredded form (which are far easier to ship), since this made them hazardous waste under the Canadian regulations. Basel cannot control trade in objects labelled 'used computers' (which is reportedly the way some recyclers have responded to the ban), but it can raise the transport costs for recycling.

By its very nature - bringing widely scattered items to one point - recycling requires transportation, and often this must occur across state boundaries. Small 
recycling plants are often not economic, since they cannot achieve economies of scale. This drives down the price they can afford to pay for scrap, diminishing the incentive to recover and deliver to a recycling plant. Worse still, small recycling plants, as with any industrial plant, often cannot afford to install the best possible control technology or implement the best environmental management practices. The worst recycling operations are undercapitalised, back-yard operations of the kind highlighted by Greenpeace. Small is not necessarily beautiful.

A study of the effects of the Basel ban on the recycling of lead-acid batteries found that the ban would reduce the price of used batteries in OECD countries and increase the overall demand for batteries to be recycled. But the lower price would reduce the collection rate for used batteries; and the number of batteries being dumped in landfill would also rise. In non-OECD countries, the price of used batteries would rise, lifting the collection rate but reducing recycling. The Basel ban would thus produce environmental benefits in unsound recycling plants in nonOECD countries (through reduced activity), but environmentally sound plants would face a shortage of batteries (BIE, 1995).

\section{Effects of the Trade Ban}

In an imperfect world there is a need to consider the consequences of any ban on trade. For example, there are five lead-acid battery recycling plants in Canada, a nation of $30 \mathrm{~m}$ people living mostly in a narrow ribbon north of the border with the US. All these plants rely upon scrap transported across the border, and few would be viable without this trade. If a restriction on trade were introduced, it would probably cause one or a number of them to close, and high transport costs would ensure that less lead was recycled and more would find its way into landfill. ${ }^{2}$ Transporting waste longer distances would also produce greater externalities, such as carbon dioxide emissions, and increase the risk of accidents.

One of the difficulties with recycling items like lead-acid batteries is that more stringent environmental controls on such industries, particularly in Europe, have similarly driven down the price that recyclers can afford to pay for lead scrap. This has had the unintended consequence of causing more lead to be dumped in landfill, as car wreckers no longer find it worth their while even to remove batteries from cars before dumping them. As a result, much of the recycling activity has moved offshore, principally to developing countries where environmental control standards are lower or less rigorously enforced. Again, there is a need to consider the consequences of regulation and develop other related policies which will ensure continued or increased recycling, rather than regulate with little consideration of the economics of the recycling industry.

The flight of recycling activities from stricter regulation in Europe is precisely what lay behind the COP-II decision banning the export of waste from OECD to

\footnotetext{
The same problem obtains with treatment and disposal. As Wynne (1987:33) noted, 'Some countries would be left with virtually no "regulation" at all if they were not free to export; others depend on imports to maintain the load factor and economic viability of domestic waste T\&D facilities'.
} 
non-OECD countries even for recycling. This is likely to impact adversely on recycling, which is bad enough from an environmental viewpoint. But the consequences are even more serious when the impact upon the development aspirations of those nations is considered.

Since a disproportionate amount of the current hazardous waste originates in OECD countries, recycling industries are likely to develop more rapidly in those countries, and developing countries will be correspondingly disadvantaged. There will be little investment in recycling in such countries, especially since a perennial problem in the waste industry is uncertainty over supply of feedstock. Worse still, as they industrialise and produce greater quantities of waste themselves, developing countries may well find much of feedstock which could support such an industry shipped to the well-established plants in OECD member nations. These would be favoured by the export ban, resulting in the persistent underdevelopment of the waste recovery and recycling industries in developing countries.

This suggests that, ironically, the Basel Convention might become an instrument of neo-colonialism generated by the developing countries themselves through their support for the ban through the G-77 bloc. Lack of scale economies and access to raw materials will hinder investment in waste facilities and produce poor environmental outcomes.

It should be pointed out that laws encouraging recycling can also lead to considerable instability in international markets by increasing supply without also increasing demand. For this reason, subsidies for recycling are often favoured, but this disrupts the market for materials gathered by scavenging in developing countries and thus deprives some of the world's poorest people of their livelihood. The German packaging law produced such an oversupply that waste collectors were paying paper manufacturers to take waste back. The glut of German paper flooded the French and British markets, producing less recycling in those countries. It resulted in the waste being sent to Indonesia, which was returned by Greenpeace at COP-II as part of its publicity campaign in favour of a ban. It also (together with the Asian financial collapse in 1997) jeopardised paper recycling in Australia, which depended on exports for its viability.

Whether the problem of international trade in hazardous wastes was so serious as to be worth these consequences is debatable. In 1993 the Basel Secretariat surveyed state parties to ascertain the occurrence of incidents causing harm from transboundary waste shipments (UNEP, 1993). Only 19 replies were received, of which ten reported no incidents of harm. Most incidents of past harm were related to an absence of notification and prior informed consent. In very few cases was consent given by nations which subsequently were unable to manage wastes. The Convention should remedy the former, and technical assistance and training are being provided to remedy the latter. Similarly, Louka (1994) provides a survey of documented cases of illegal trade and finds very few to report. 


\section{Morality vs Practicality}

Successful regulation of hazardous waste requires that we put our sense of moral outrage aside, even though 'blame and shame' tactics can be powerful factors making for consensus in international negotiations. We need, instead, to concentrate our attention on the characteristics of the problem which make successful regulation problematic.

First, as Wynne (1987:55) notes (and as Greenpeace has claimed), investment in adequate treatment and disposal facilities creates a vested interest against successful 'upstream' waste reduction, because of the need to run facilities such as incinerators at full capacity (see also Louka, 1994:32). This raises the issue of how existing or inevitable wastes are to be handled. Second, waste reduction is encouraged by increasing the costs of treatment and disposal, but this is effective only if the higher costs do not push the wastes into illegal disposal or export to cheaper alternatives. Even a cumbersome PIC regime might be sufficient to create perverse incentives (Louka, 1994:31). Further, encouragement of waste recycling 'requires loosening restrictions on waste definitions, movements, and exchanges, so as to allow entrepreneurial wisdom the scope to identify valuable resources in others' wastes' (Wynne, 1987:55).

The operation of incinerators impacts upon recycling by removing materials which might be recycled, but this ignores the point that the positive value attached to materials is likely to be the primary determinant of whether they will be recycled. The instability of markets for recycled materials is likely to be a more significant influence, and (ironically) policies encouraging or requiring recycling can contribute to this instability by increasing supply. Further, subsidised recycling can result in illegal waste trafficking (as occurred with the German packaging law), and can distort competition in developing countries.

Even in Denmark, where the Kommunekemi disposal facility was operated by municipalities (with intractable waste shipped to Germany for disposal in salt mines), illegal dumping occurred because it was cheaper than incineration. This underscores the importance of trade in wastes to ensure economies of scale so that legitimate disposal can compete with illegal dumping - though improved detection and increased penalties for illegal dumping are also needed. The waste processing industry is particularly susceptible to the loss of raw materials, which poses serious risks for investors. Export bans amount to import protection for this industry because of the negative economic value of the raw material; and environmentalist demands for export bans coincide with the desire for industry protection from exports. For this reason, Germany had adopted laws which (in contravention of the Treaty of Rome) banned exports from each Land (Wynne, 1987:33).

Finally, efforts to punish wrongdoers fairly requires extensive litigation, which can conflict with an expeditious clean-up. As has been recognised with accidents, the process of apportioning blame can result in few resources being left over to compensate the losers. We have developed no-fault road accident insurance, nofault divorce law, and no-fault medical insurance because blame attribution was consuming so many resources in litigation that there was little compensation left 
with which to rehabilitate the victims (Calabresi, 1970). Yet in many ways hazardous-waste policy at both the domestic and international levels can be seen to be precisely about blame. Douglas (1992:16) argues that the new aversion to risk provides a new blaming system under which every death is 'charged to someone's account'. One dilemma in devising effective policy is that some sense of responsibility is necessary to ensure behaviour that minimises risk, yet too great an emphasis on blame obstructs practical policy.

The Basel Convention, along with its other uses, provides a convenient system of blame attribution, which in developing countries absolves national elites from responsibility for the pollution which emanates from recycling plants. But recycling plants do not constitute a special case, and backyard lead recycling is no more of a problem than small-scale gold miners inhaling mercury fumes. Both can have tragic consequences that can be addressed only by effective local regulation. As Shrivastava (1995) has pointed out, management of technological risks in developing countries will require democratic mechanisms similar to those found in advanced industrialised countries, and this is likely to constitute a direct challenge to many national elites. Better to attribute damage to the West, or the North. In the West, the Basel Convention helps blame large corporations for ills which are real enough, but exaggerated. Its blame-attribution functions thus suit the politics of developing countries and also social movement politics (where campaigning on the basis of moral virtue and sin produces cohesion and helps generate support). However, it can be seen not just to have obstructed the development of effective policy, but to have resulted in policy with considerable potential for counterproductive effects.

The real problem with recycling in developing countries stems from inadequate environmental regulation at the level of national or subnational governments, whether through the failure to adopt adequate legislation or through the failure to enforce legislation which does exist. As Ibrahim Wani (1991:37) has noted, the 'poverty in developing countries, which makes importation of hazardous waste so tempting, is a function of the poor quality of their governments and the absence of the rule of law'. In addition, 'poor governance and the absence of the rule of law is a disincentive to effective environmentalism'. Often this failure is inadvertent: effective policy design and implementation is problematic anywhere. But, just as often, it is deliberate, aimed at ensuring a competitive advantage over nations where the costs of environmental compliance are higher, and motivated by a misplaced belief in the pollution haven theory. Either way, national elites and transnational corporations alike are assisted in keeping costs down through either environmental damage or damage to workers' and citizens' health.

\section{Who Are the Bootleggers?}

As noted earlier, international prohibition regimes usually prove to be ineffective in suppressing activities which have many of the same characteristics as hazardous waste (Nadelmann, 1990:486). The worst kinds of bootleggers in the Basel case are therefore more likely to be known to Interpol than to the Secretariat of the Basel Convention. Environmental crime is a growth industry and Interpol has established 
a division to deal with it. There are other interests, however, which have helped drive the international regime in the direction of poor policy design, and these must be taken into account in any attempts to reform the regime. Our analysis enables us to identify among the interests that are advantaged by the Basel Convention the waste management industry within Annex VII Parties (effectively OECD nations) that are given protection from foreign competition. They are also assisted by international obligations that counter domestic opposition to siting their facilities.

Similarly privileged are the domestic suppliers of environmental technologies, who construct treatment facilities and new industrial plant capable of achieving cleaner production. Much of this activity will lead to better environmental outcomes, although the dialectics of waste mean that success here will make investment in waste treatment all the more problematic.

Benefits will flow to consumers of recyclable secondary raw materials such as metals fabricators in Annex VII nations. Bans on exports will drive down prices for scrap, and metals fabricators have interests which diverge from those of producers of primary metals. For the same reasons, however, local primary metals producers in non-Annex VII countries will gain from diminished competition from imports of secondary raw materials. Some nations use trade barriers to protect domestic production, and the Basel ban might provide another non-tariff barrier.

Behind the moral dimension to Basel there lie many 'bootlegger' interests which are favoured by the prohibition regime the Convention establishes. Alone, they are not decisive in supporting a regime which is quite possibly more costly and ineffective than it needs to be; but they contribute towards the asset of national interest each of the Parties brings to negotiations. The moral arguments advanced by Greenpeace and other members of the Basel Action Network are more decisive. Global prohibition regimes are driven by a sense of evil and are likely to pay little heed to costs and consequences: like crusades, they are instigated and pursued even when alternative approaches appear less costly and more effective' (Nadelmann, 1990:525).

This combination of baptists and bootleggers has shaped the Basel Convention thus far. If we were designing an effective international regime to deal with hazardous wastes, we would be unlikely to come up with the Basel Convention. We would probably devote more attention to enhancing the capacities of developing countries to make their own decisions about whether to accept wastes or secondary raw materials, to regulate such industries as they decided to accept, and to police their borders to enforce those decisions. Even with Basel, we should not forget that these elements are still required. The focus on export bans obscures these needs, and the practicalities of international politics probably mean that we must work towards them within a framework of bad policy rather than design better policy. 


\section{References}

Allen, R. (1992), Waste Not, Want Not: The Production and Dumping of Toxic Waste, Earthscan/World Wildlife Fund, London.

Bureau of Industry Economics (BIE) (1995), Implications of a Ban on Exports of Used Lead Acid Batteries, Canberra (Occasional Paper 31).

Calabresi, G. (1970), The Costs of Accidents: A Legal and Economic Analysis, Yale University Press, New Haven.

Douglas, M. (1992), Risk and Blame, Routledge, London.

Greenpeace International (1994). 'We Did It! Banning the International Waste Trade', Newsletter, No. 1.

Hoffman, U. (1995), A Statistical Review of International Trade in Metal Scrap and Residues, ICME, Ottawa.

Louka, E. (1994), Overcoming National Barriers to International Waste Trade: A New Perspective on the Transnational Movements of Hazardous and Radioactive Wastes, Graham \& Trotman/Martinus Nijhoff, Dordrecht.

Nadelmann, E. (1990), 'Global Prohibition Regimes: The Evolution of Norms in International Society', Intemational Organization 44: 479-526.

Shrivastava, P. (1995), 'Democratic Control of Technological Risks in Developing Countries', Ecological Economics 14: 195-208.

Thompson Environmental Services (1995), Review of Policy on Trade in Hazardous Wastes for Recovery: Elcctrical and Electronic Scrap, Canberra, November.

United Nations Environment Program, Secretariat of the Basel Convention (UNEP) (1993), Report on the Factual Basis Received from the Parties to the Bascl Convention on the Subject of Liability and Compensation for Damage Resulting from the Transboundary Movements of Hazardous Wastes and Their Disposal, Geneva.

Veldhuizen, H. \& B. Sippel (1994), 'Mining Discarded Electronics', UNEP Environment and Industry (July-September): 7-11.

Wani, I. (1991), 'Poverty, Governance, the Rule of Law, and International Environmentalism: A Critique of the Basel Convention on Hazardous Wastes', Kansas Journal of Law and Public Policy 1: $37-49$.

Wynne, B. (1987), Risk Management and Hazandous Waste: Implementation and the Dialectics of Credibility, Springer-Verlag, Berlin.

Yandle, B. (1989), The Political Limits of Environmental Regulation, Quorum Books, New York.

An earlier version of this article was presented to the PECC Minerals Forum, 'The Basic Problems of the Basel Convention: What Can be Done?', Melbourne, August 1998. It draws on material in International Toxic Risk Management: Ideals, Interests and Implementation, to be published by Cambridge University Press. 